\title{
Maps, Tables, and Figures
}

MAPS

Map I. China, I945-I950

Map 2. Korea, I950-I953 xvii

Map 3. The Fifth Offensive, Second Phase

Map 4. Koje POW Camp, I952 I87

Map 5. Camp 3A for Chinese Communist POWs, Cheju City 309

TAB LE S

Table Io.I. Screening results in major Chinese POW compounds, April 1952

Table I2.I. Major differences between pro- and anti-repatriation POWs 286

Table I4.I. Prisoner exchange in Little Switch and Big Switch, I953 33 I

Table I 4.2. Disposition of Non-Repatriation Prisoners in late I953 and early 1954

Table I 5.I. Prisoner-agents' alleged escape dates versus actual capture dates

FIGURES

Figure o.I. Chinese People's Volunteer Army prisoners with Nationalist

flags and portraits of Sun Yat-sen and Chiang Kai-shek

Figure 0.2. Chiang Kai-shek's portrait 3

Figure 4.I. General MacArthur and President Chiang Kai-shek 85

Figure 5.I. X Corps commander Almond and the first group of Chinese prisoners captured in Korea

Figure 6. I. Captured Chinese soldiers questioned by ROK and US officers 
Figure 7.I. Two female members of the Eighth Army Psychological

Warfare Section don parachutes in a C-47 aircraft

Figure 7.2. A captured Chinese prisoner urges his comrades to surrender

Figure 7.3. Chinese prisoners at the 2 Ist Regiment HQ, 24th US Infantry Division

Figure 7.4. Wounded Chinese prisoners treated at the 2 Ist Regiment, 24th US Infantry Division collection station

Figure 7.5. Chinese prisoners inspected by James Van Fleet, William Sebald, and Matthew Ridgway

Figure 8.I. Prisoners sleeping in a flipped-spoon fashion in overcrowded tents

Figure 8.2. Prisoner details carrying "honey buckets" to be emptied into the sea

Figure 8.3. Flag-raising ceremony in Compound 86

Figure 8.4. Chinese prisoners with tattoos of Nationalist flags and anti-Communist slogans

Figure 9. I. UNC liaison officers meeting Communist counterparts

Figure 9.2. UNC and Communist liaison officers initialing a map showing the I 45 -mile line of demarcation

Figure Io.I. POWs interviewed regarding their repatriation choices

Figure I 0.2. Mutilated bodies of Lin Xuebu, Zhang Zhenlong, and Cao Lixing

Figure I0.3. The POW record card of Yang Wenhua

Figure I I.I. Koje POW camp commandant Haydon Boatner

Figure I I.2. Postmortem photographs of Wang Huayi

Figure II.3. A sketch by prisoner Wu Chunsheng depicting a funeral in Compound 602

Figure I2.I. Captain Joseph Brooks and DAC interpreter Huang Tiancai $\quad 289$

Figure I2.2. UNC surrender leaflet

Figure I2.3. Maximum-security cell on Koje

Figure I3.I. Homemade weapons uncovered after the October I massacre 3 I 6

Figure I4.I. Chinese Communist POWs shouting slogans at the

Panmunjom exchange point 
MAPS, TABLES, AND FIGURES

Figure I4.2. Chinese anti-Communist prisoners staging the beheading of "Bandit Mao Zedong"

Figure I 4.3. Chinese Communist POWs transferred for repatriation

Figure I4.4. Chinese anti-Communist prisoners saluting the visiting

Nationalist delegation from Taiwan

Figure I 5.I. POW roster page 
This page intentionally left blank 